\title{
Screening of Turkish Melon Accessions for Resistance to ZYMV, WMV and CMV
}

\author{
Ercan EKBIC ${ }^{1)}$, Hakan FIDAN ${ }^{2)}$, Mehtap YILDIZ3), Kazım ABAK ${ }^{4)}$ \\ 1)Adiyaman University, Kahta Vocational School, Adiyaman,Turkey; ercanekbic@gmail.com \\ ${ }^{2)}$ Plant Protection Research Institute, Adana,Turkey; hakanfidantr@hotmail.com \\ 3) Yuzuncu Yil University, Faculty of Agriculture, Department of Horticulture, Van, Turkey; mehtapyildiz@gmail.com \\ 4) Cukurova University, Faculty of Agriculture, Department of Horticulture, 01330 Balcali, Adana, Turkey; abak@cu.edu.tr
}

\begin{abstract}
In the Çukurova University Department of Horticulture more than 350 melon accessions were collected from different ecological parts of Turkey which is located on the secondary genetic diversification center of this crop, and their characterization studies are near completion. Furthermore, evaluation studies of these materials have started. In the present study 67 melon accessions, sampled from this germplasm, were tested for resistance to zucchini yellow mosaic virus (ZYMV), Cucumber mosaic virus (CMV) and watermelon mosaic virus (WMV). After resistance tests made by mechanical inoculation, four accessions ('CU 100', 'CU 287', 'CU 305' and 'CU 328 ') were found resistant to ZYMV and three accessions ('CU 305, 'C 264', and 'C 276') to WMV. No resistant genotype was found to CMV.
\end{abstract}

Keywords: Cucumis melo, melon, germplasm, virus, resistance

\section{Introduction}

Melons have much importance, in human nutrition and for economic values, being represented in the world with 27 million tones on 1.2 million ha area yearly production. Turkey is a leading producer of melon, being on the second place among the world producer countries, with about the 1.8 million tones production, realized on 115 thousand ha area (Anonymous, 2005). Cultivated melon $(85 \%)$ consists of inodorous melon group (Kirkagac, Hasanbey, Yuva etc.) and the rest (15\%) is composed by reticulatus and cantalupensis types (ie. Ananas, Galia etc.) in Turkey (Abak, 2001).

Viral diseases cause important economic losses throughout the world. More than 35 viruses have been isolated from cucurbits (Provvidenti, 1996). These viruses constitute complex and dynamically changing problems as described by Nameth et al. (1986). Most commercial melon varieties are susceptible to the viral pathogens. Potyviruses form the largest and the most economically significant group of plant viruses (Riechmann et al., 1992). Severe losses in melon production areas are due to potyvirus infection, including watermelon mosaic virus (WMV), zucchini yellow mosaic virus (ZYMV) and papaya ringspot virus (PRSV) (Davis and Mizuki, 1987; Provvidenti and Gonsalves, 1984). Infected melon plants may show vine decline, reduced or absent yield and fruit quality defects.

Virus infections caused by nonpersistently transmitted viruses are difficult to prevent by insecticide application
(Raccah, 1986), which is the most frequent measure used by growers. Therefore, incorporation of genetic resistance in the host plant is a valuable alternative. Commercial melons carrying resistance to cucumber mosaic virus (CMV) and PRSV are available (Lecoq et al., 1998). However, resistant cultivars to ZYMV or WMV are not commercially available (Danin-Poleg et al., 2000; Pitrat and Lecoq, 1984; Gilbert et al., 1994; Gray et al., 1988).

Melon is a diploid species of African origin and Turkey is not a center of origin of this crop. Hence, there are no wild types or forms of genera such as Cucumis, Cucurbita, Citrullus, Lagenaria etc. However, Anatolia peninsula is situated on the second genetic diversification center for these plants (Robinson and Decker-Walters, 1997; Pitrat et al., 1999) and a rich genetic diversity of melon, watermelon, snake cucumber, squash and pumpkin found in that area (Harlan, 1951; Kucuk et al., 2002). In the Ministry of Agriculture and Rural Affairs, a special service was established in 1964 for plant genetic resources and a national framework was implemented. The Aegean Agricultural Research Institute (AARI) has taken responsibility of projects of this kind. About 1600 cucurbit accessions (350 melons) have been collected within this institute. On the other hand, nearly 400 melon accessions were collected from different ecological parts of Turkey by the University of Çukurova, Department of Horticulture, and their characterization studies are near completion. Furthermore, evaluation studies of these materials have started, searching for the resistance to diseases: Fusarium oxysporum f. 
56

sp. melonis, Pseudomonas viridiflava and some viruses. The objective of the present work was to search for novel sources of resistance to ZYMV, CMV and WMV, in Turkish C. melo germ plasm collection, and to use this resistance sources in further breeding studies.

\section{Materials and methods}

In the study 65 melon accessions including inodorous, reticulatus and cantalopensis groups ('CU04', 'CU16, 'CU34', 'CU51', 'CU67', 'CU99', 'CU100', 'CU104,' 'CU172, 'CU177,' 'CU179,' ‘CU180, ‘CU190, 'CU193, 'CU196,' 'CU199,' 'CU203,' 'CU204,' 'CU206, 'CU227, 'CU230, 'CU233', 'CU235, 'CU236, 'CU239', 'CU241', 'CU243', 'CU245', 'CU252, ‘CU256, 'CU265', 'CU272,' 'CU287, 'CU297', 'CU306, 'CU307, 'CU308, 'CU315', 'CU316, 'CU319', 'CU320, ‘CU328, ‘CU329', 'CU331', 'CU334,' 'CU335,' 'CU336,' ‘CU337,' ‘CU338', 'CU340, 'CU341', 'CU342', 'CU343, 'CU344,' 'CU345', 'C157,' 'C264', 'C276, 'C285, 'C824,' 'Cum334,' 'Çesme', 'Kurkagaç', 'Negro' and 'PMR45') and two wild relatives ('CU305', 'CU332') were evaluated for resistance to CMV, ZYMV and WMV. Thirteen accessions were provided from INRA-Montfavet, and eigth from Spain SIA-DGA and La Mayora-C.S.I.C. Screening tests were carried out at University of Çukurova and Adana Regional Plant Protection Research Institute. Virus isolates ZYMV- 'CU0190', CMV- 'CU0172' from Çukurova University and WMVZM from Izmir Plant Protection Research Institute were used for the study. All virus isolates were propagated by mechanically inoculation onto the susceptible melon plants, and then tested by ELISA method for confirmation before using in trials. Plants were growth in $4 \mathrm{~cm}$ diametered multi cellular trays. Virus isolates were mechanically inoculated to the cotyledons at the first true leaf stage of the plant by rubbing Carborundum-dusted with extracts from $1 \mathrm{~g}$ of infected plant material prepared in $0.02 \mathrm{M}$ phosphate buffer and containing 0.1\% 2-mercaptoethanol ( $\mathrm{pH}: 7.0)$ and added activated carbon. After inoculation cotyledons were washed using tap water. Plants were left to grow in 16 $\mathrm{h}$ light $8 \mathrm{~h}$ dark at $25^{\circ} \mathrm{C}$ temperature conditions. Presence or absence of virus symptoms was scored for each test plant 3 weeks after inoculation. The accessions, developed visual symptom, were recorded as susceptible and symptomless plants resistant. Then symptomless plants were controlled by ELISA test to confirm resistance.

\section{Results and discussion}

In this work, forty six melon accessions representative of various geographical regions of Turkey, thirteen from France and eigth from Spain were screened for resistance to CMV, WMV, and ZYMV, especially for other than known mechanisms of resistance to these diseases, to evaluate our melon germplasm. Results of the resistance tests are summarized in Tab. 1.
Tab. 1. Results of mechanical inoculation of C. melo and wild relatives tested with CMV, WMV and ZYMV

\begin{tabular}{cccc}
\hline \multicolumn{4}{c}{ Number of $C$. melo $/$ number of wild relative } \\
\hline Virus Tested & Susceptible & Resitant & Total \\
CMV $^{*}$ & $65 / 2$ & $0 / 0$ & $65 / 2$ \\
WMV & $63 / 1$ & $2 / 1$ & $65 / 2$ \\
ZYMV & $62 / 1$ & $3 / 1$ & $65 / 2$ \\
\hline
\end{tabular}

${ }^{*}$ After CMV test 29 accessions were found to be susceptible and 38 accessions did not produced clear symptoms. Therefore all genotypes tested by ELISA and all gave positive reaction.

The results show that there was no resistance to CMV in tested accessions. Among 67 accessions, 'CU305'- a wild relative of melon (C. melo var. agrestis) collected from Adana, was found to be resistant to both ZYMV and WMV. 'CU100' (collected from Turkmenistan), 'CU287' (collected from eastern Anatolia) and 'CU328' (collected from central Anatolia) were also observed resistant to ZYMV. Accessions 'C264' and 'C276' (both obtained from Spain) showed resistance to WMV, together with the 'CU305'. The type or heritability manner of the resistance of these accessions was not tried in the study. As seen in Tab. 1, the virus resistance source is very limited in the melon cultivars. There is no resistance in the commercial varieties, but some melon lines have good resistance to viruses. The Indian accession PI 414723 (McCreight et al., 1992) possesses multiple disease and pest resistances. Anagnostou et al. (2000) identified that a breeding line derived from PI 414723 has multiple resistance to WMV, ZYMV, PRSV and powdery mildew. Its resistance to WMV is governed by a single dominant gene WMV. Pitrat and Lecoq (1984) identified a single dominant gene, ZYM, in the same accession PI 414723 for resistance to ZYMV. Another melon accession- PI 161375, confers heterogeneous resistance to CMV (Diaz et al., 2003). This accession confers a complete resistance to M-373 and some plants gave symptoms when inoculated by B-20.2 and M-6 strains of CMV.

For the further studies, the rest of our melon germplasm will be evaluated for virus and other diseases, and the mechanisms of virus resistances will also be studied.

\section{Acknowledgements}

This study was supported financially by grant "ZF2004BAP4" of the Çukurova University Academic Research Projects Unit, and as for the plant material by the "EUGENRES-108" program (European Union). We wish to thank Suat Sensoy from Yuzuncuyıl University Turkey, Michel Pitrat from INRA France and Maria LuisaGomezGuillamon from CSIC La Mayora Spain for providing germplasm. 


\section{References}

Abak, K. (2001). Melon growing in Turkey. Proceeding of $23^{\text {rd }}$ Geisenheim Meeting. 12-14 Feb. Frankfurt, Germany. 6468.

Anagnostou, K., M. Jahn and R. Perl-Treves (2000). Inheritance and linkage analysis of resistance to zucchini yellow mosaic virus, watermelon mosaic virus, papaya ringspot virus and powdery mildew in melon. Euphytica. 116:265-270.

Anonymous (2005). Faostat. Statistic database. http://www.fao. org.

Danin-Poleg, D., G. Tzuri, N. Reis, Z. Karchi and N. Katzir (2000). Search for molecular markers associated with resistance to viruses in melon. Acta Hortic. 510:399-403.

Davis, R. F. and M. K. Mizuki (1987). Detection of cucurbit viruses in New Jersey. Plant Disease 7: 40-44.

Diaz, J. A., C. Mallor, C. Soria, R. Camero, E. Garzo, A. Fereres, J. M. Alvarez, M. L. Gomez-Guillamon, M. Luis-Artega and E. Moriones (2003). Potential source of resistance for melon to nonpersistently aphid-borne viruses. Plant Disease. 87: 960-964.

Gilbert, R. Z., M. M. Kyle, H. M. Munger and S. M. Gray (1994). Inheritance of resistance to Watermelon mosaicvirus in Cucumis melo L. HortScience 29:107-110.

Gray, S. M., J. W. Moyer and G. G. Kennedy (1988). Resistance in Cucumis melo to watermelon mosaic virus 2 correlated with reduced virus movement within leaves. Phytopathology 78:1043-1047.

Harlan, J. R. (1951). Anatomy of gene centers. Am. Nat. 85:95103.

Kucuk, A., K. Abak and N. Sari (2002). Cucurbit genetic resources collections in Turkey. Cucurbit Genet. Resources in Europe (compliers Diez, M.J., Pico, B. and Nuez, F.), Ad
Hoc Meeting, 19 January 2002, Adana, Turkey. 46-51.

Lecoq, H., G. C. Wisler and M. Pitrat (1998). Cucurbit viruses: The classics and emerging, p. 126-142. In: J. D. McCreight (Ed.). Cucurbitaceae '98, evaluation and enhancement of cucurbit germplasm. ASHS, Alexandria, VA.

McCreight, J. D., G. W. Bohn and A. N. Kinshaba (1992). 'Pedigree' P.I. 414723 melon. Cucurbit Genet. Coop. Rpt. 15:51-52.

Nameth, S. T., J. A. Dodds, A. O. Paulus and F. F. Laemmlen (1986). Cucurbit viruses of California: an ever-changing priblem. Plant Disease 70:8-11.

Pitrat, M. and H. Lecoq (1984). Inheritance of zucchini yellow mosaic virus-resistance in Cucumis melo. Euphytica 33:5761.

Pitrat, M., M. Chauvet and C. Foury (1999). Diversity, history and production of cultivated cucurbits. Acta Hort. 492:2128.

Provvidenti, R. and D. Gonsalves (1984). Further occurrence of zucchini yellow mosaic virus in the United States. Cucurbit Genet. Coop. Rpt. 7:80.

Provvidenti, R. (1996). Diseases caused by viruses. p. 37-45. In: T. A. Zitter, D. L. Hopkins and C. E. Thomas (Eds.). Compendium of Cucurbit Diseases. PS Press, St. Paul, Minn.

Raccah, B. (1986). Nonpersistent viruses epidemiology and control. Adv. Virus Res. 31:387-429.

Riechmann, J. L., S. Lain and J. A. Garcia (1992). Highlights and prospects of potyvirus molecular biology. J. Gen. Virol. 73:1-16.

Robinson, R. W. and D. S. Decker-Walters (1997). Cucurbits. CAB International, Oxon (UK). p. 226. 